\title{
Economic Reforms and the Performance of Nigeria's Manufacturing Sector from (1981-2012)
}

\author{
Ighosewe Enaibre Felix ${ }^{1} \&$ Akpokerere Othuke Emmanuel ${ }^{2}$ \\ ${ }^{1}$ Dept. of Accounting, Banking and Finance, Faculty of Management Science, Delta State University Asaba \\ Campus, Asaba, Nigeria \\ ${ }^{2}$ Department of Banking/Finance, School of Business Studies, Delta State Polytechnic, Ozoro, Nigeria \\ Correspondence: Ighosewe Enaibre Felix, Dept. of Accounting, Banking and Finance, Faculty of Manangement \\ Science, Delta State University Asaba Campus, Asaba, Nigeria. Tel: 234-803-260-1813. E-mail: \\ felixighosewe@yahoo.com
}

Received: June 30, 2014

Accepted: March 2, 2015

Online Published: March 25, 2015

doi:10.5539/ibr.v8n4p281

URL: http://dx.doi.org/10.5539/ibr.v8n4p281

\begin{abstract}
This research examines the effects of economic reforms (NEEDS) on the performance of Nigeria Manufacturing Sector and also determines how the manufacturing sector supports employment generation in Nigeria. In the pursuit of the objective of the study, secondary data was used. Data were sourced from statistical Bulletin Economic and Financial Review, Annual Reports and Statement of Accounts of the Central Bank of Nigeria (CBN) and the Federal Office of Statistic (FOS). Data obtained, were analyzed using an Ordinary Least Square method by the use of time series data. The result shows the unemployment before reform is significantly less than it was during reform. Also poverty rate before reform is significantly less than it was during reform and the study concludes that reform should be timely and effective in addressing the problem of the populace with proper follow-up by the policymakers. Base on the findings, the study recommends amongst others that policy makers should provide infrastructural development to create a conductive environment for the manufacturing sector growth.
\end{abstract}

Keywords: economic reforms, reformation, productivity, manufacturing, unemployment rate

\section{Introduction}

The manufacturing sector plays a catalytic role in a modern economy which has many dynamic benefits crucial for economic transformation. In any advanced economy or even growing economy, the manufacturing sector is an avenue for increasing productivity in relation to import replacement and export expansion, creating foreign exchange earning capacity, rising employment and per capital income, which causes unique consumption patterns. It creates investment capital at a faster rate than any other sector of the economy while promoting wider and more effective linkages among different sector (Alao, 1995).

Previously hindered by years of mismanagement, economic reforms of the past decade have put Nigeria back on track achieving its full economic potential. Nigeria GDP at purchasing power parity (PPP) has almost tripled from $\$ 170$ billion in 2000 to $\$ 451$ billion in 2012, although estimates of the size of the information sector put the actual numbers closer to $\$ 630$ billion.

The birth of democratic era in Nigeria supports "private-sector" led, "market oriented" economic growth and extensive economic reform efforts. During the year 2000, the government's privatization program showed signs of life and real promise with successful turnover to the private sector of state-owned banks, fuel distribution companies, and cement plants. The successful auction of GSM telecommunication licenses in January 2001 has encouraged investment in this vital sector.

In recent time, the transformation agenda of the President Jonathan is aimed at improving capacity utilization in Nigeria's manufacturing sector and has help to increase local content linkages with other sectors of the economy, ensuring global competitiveness for manufactured goods and achieving rapid and sustained economic growth through breeding of nation's productive base. This reform has had its positive impact on the manufacturing as CBN reported that Nigeria economy had been growing at seven percent rate annually and might double in the next ten years (CBN report, 2012). 
According to Adesanya (2014), the reform of manufacturing sector in Nigeria has led to $7.7 \%$ improvement in the sector compared to the past records. This is an indication of significant improvement in the sector based on the reform.

Despite Nigeria's immense economic reforms which were all aimed at improving industrial production and capacity utilization of the manufacturing sector, there are still growing concern on the decline of the output of the sector in recent times.

During the year 1999, human development indicators of Nigeria were below average in comparison with other developing economies. Nigeria depended strongly on its oil export business, leading the country vulnerable to fluctuations in oil prices. Volatile fiscal spending was destabilizing the country's macroeconomic conditions. This volatile economic environment deterred private investment; at the same time, government expenditures were rising. The unemployment rate in Nigeria was quite high. The Nigeria citizens' average income pre capita was very low, below $\$ 300$ (World Bank Report, 2010).

The government's plan to tackle these problems included structural, institutional, governance, and macroeconomic reforms. Economic reform was first introduced in Nigeria in 2003, during the second term of President Olusegun Obasanjo was known as the National Economic Empowerment and Development Strategy (NEEDS). The government aimed to improve the macroeconomic environment within Nigeria and to better manager public expenditures. Structural reforms played a large role as well.

Due to the reform of manufacturing sector, the country has experienced significant growth in the sector which has led to significant reduction in the unemployment rate and has led to improvement in the GDP of the country (Adesanya, 2014). Non growth of the sector could have adverse effect on the populace as it could lead to increase in unemployment rate, weakness of Nigeria economy, and increase in importation rate with decrease in rate of exportation in the country.

The objective of this study is:

1) To examine the effect of economic reform (NEEDS) on the performance of Nigeria's manufacturing sector.

2) To determine how the manufacturing sector supports employment generation in Nigeria.

The following hypotheses statement was tested:

Ho1: Economic reform adopted in Nigeria called NEEDS has led to insignificant improvement in the manufacturing sector.

Ho2: The reform could not significantly alleviate unemployment in Nigeria.

The study stands to validate or nullify the findings of previous researchers on the problem identified using the most current information available in the selected sector.

Also, it will help policy maker in the country develop appropriate polices that will accelerate the performance of manufacturing sector in Nigeria

The study focuses on the effect of NEEDS as one of the economic reforms introduced in Nigeria on the performance of manufacturing sector. The research covers the period of 30 years divided into two, namely before the reform data between 1981 and 1998 and during the reform (1999-2012). However the study is restricted to a particular reform called NEEDS in the manufacturing sector in Nigeria.

\section{Conceptual Framework}

Reformation is one of the most important instrument of resuscitating sector while production is the efficiency with which outputs are produced; ratio of output to input (Craig \& Harris, 1973). Among the main functions of managers conservative use of available resource due to its scarcity to achieving maximum possible result in terms of profit. This implies production is concern with the overall effectiveness and efficiency of getting things done.

The main objective of every business is wealth maximization and minimization of loss to ascertain the survival of the business in the long-run. A business with insignificant profit margin would eventually go on extinction but significant growth in profit margin would lead to growth of the business and guarantee the future of the business. This implies proper management of available resources is an important factor in very venture. Significant increase in profit margin of an establishment would lead to continuous production and survival of such sector.

In the case of significant growth of a business, reformation becomes a necessity to redirect the approach used in solving problems. Therefore, reformation is keen to resuscitation of dying business or sector. 


\subsection{Theoretical Review}

This study is anchored on the theory of productivity. Productivity is the ratio of output to input in production; it is a measure of production.

Business Managers sees productivity not only as a measure of efficiency, but also connotes effectiveness and performance of individual organization. For them, productivity would incorporate quality of output, workmanship, adherence to standards, absence of complaints, customer satisfaction (Udo-Aka, 1983). The administrator is more on those factor which are more operational and quantifiable, work measurement and performance standards (Adekoya, 1989). Productivity can be computed for a firm, industrial group, the entire industrial sector or the economy as a whole. It measure the level of efficiency at which scarce resources are being utilized. Productivity can now be simply summarized as the rate of real output per unit of input. It is measured as a ratio of output per unit of input overtime. It is a measure of efficiency and is usually considered as output per person hour. It can be expressed as the following ratio;

$$
\text { Production }=\frac{\text { Real output }}{\text { Input }}
$$

An increase in productivity is said to occur when output is produced either with the same amount of input, or with less input or with little increment in input.

\subsection{Background of the Nigeria Manufacturing Sector}

Perhaps, owing to the complexities involved in constructing productivity index there is little or no data on productivity levels in Nigeria economy in general and the manufacturing sector in particular. Adhoc Studies conducted during 1989 indicated that, on the average, there was little rise in productivity (Akinlo, 1996).

According to Oshoba (1989) on food and basic metal industries, only 30 percent of respondents indicated they has rising productivity. About 11 percent recorded no growth while more than half, 57 percent recorded declining productivity levels.

In the same vein, the Manufacturing Association of Nigeria (MAN) confirmed that the general trend in productivity industry was negative in 1989 to 1999 and after 2003, the economic reforms impacted positively on the manufacturing industries in Nigeria (MAN report, 2010).

Nigeria manufacturing industry has suffered from neglect, since the country's economy has been depending on the petroleum sector since 1970 s, as the government tries to diversify the economy; it is working to reinvigorate the manufacturing sector so as to increase its contribution to Nigeria's prosperity.

MAN (2001) noted that automobile industry such as Peugeot Automobile of Nigeria (PAN) Nolkswagen of Nigeria (VON), Leyland Nigeria Limited have been grounded which result into huge loss of jobs, reduction in Gross Domestic Product (GDP) and importation of second hand vehicle parts and spare parts christened "Tokunbo" at the detriment of local plant.

Obasanjo Administration improved the performance of manufacturing sector through national Economic Empowerment and Development Strategy (NEEDS), State Economic Empowerment and Development Strategy (SEEDS), and Local Economic Empowerment and Development Strategy (LEEDS) at Federal State and Local Government Levels between, spans 2003-2007 while Yar'Adua's administration incorporated and prioritized manufacturing sector in his seven-point agenda. President Goodluck Jonathan in his transformation agenda aimed to improve capacity utilization in Nigeria manufacturing sector and global competitiveness for manufacturing goods.

High productivity in the Nigeria manufacturing sector has been constrained by many factors which include the followings:

(a) Low level of Capacity Utilization Rate: Capacity utilization rate in the manufacturing sector is between 30 and 40 percent, indicating gross under utilization of resources. This has been blamed largely on frequent strikes and lockouts by worker and their employed.

(b) Low Investments: Lack of funds has made it difficult for firms to make investments in modern machines, information technology and human resource development which are critical in reducing production costs, raising productivity and improving competitiveness.

(c) Poor Performing Infrastructure: Poor performance of infrastructural facilities, characterized by frequent disruption in electric power and water supplies and inefficient telecommunication and transportation system, is a major constraint on productivity. As firm have to invest huge capital to provide alternative 
infrastructural facilities to run their businesses, enterprise are forced to carry high cost structure which reduces efficiently and results in loss of competitiveness for their production.

\section{Methodology}

\subsection{Research Design}

The study utilized ordinary Least Square (OLS) method of analysis. OLS is used for estimating unknown parameters in linear regression model. Regression is used to capture necessary variables needed in the study for better understanding and result which could aid decision making among planners.

\subsection{Sources and Data Collection}

This study makes use of secondary time series data sourced from Statistical bulletin, Economic and Financial Review and Annual reports and Statement of accounts of the Central Bank of Nigeria (CBN) and the Federal Office of Statistics (FOS). The macro data cover the output of manufacturing sector and the variables of economic reforms in Nigeria from 1981 to 1998 (before the reform) and 1999 to 2012 (during reform).

\subsection{Model Specification}

The Linkage between trade policy reform and the manufacturing sector has occupied a central position in development. Examining the relationship between reforms and manufacturing sector in Nigeria, ordinary Least Square (OLS) method of analysis was used.

$$
R M S O=B O+B 1 E M P+B 2 R G D P+B 3 L S+B 4 P L+e i
$$

Where,

RMSO is Real Manufacturing Sector Output;

EMP is Employment;

RGDP is Real Gross Domestic Product;

LS is Loan Assessment; and

PL is Poverty Level.

The variables were included in the model based on the aims of the reform as stated by federal government of Nigeria. The reform is set to reduce unemployment rate, increase RGDP, easy assessment to loan and great reduction in the poverty line of the populace. The performance of manufacturing sector was measured using Real manufacturing Sector Output (RMSO) which serves as dependent variable. The ei in the model is error term or unexplained variable which might have effect on the dependent variable.

\subsection{Test of Hypothesis}

The estimates of the function will be tested using the following:

(a) Aprior/Expectation Test;

(b) Statistical Expectation Test.

\subsubsection{Aprior/Expectattion Test}

This test checks the relationship between the dependent and independent variable to see whether their relationship meet theoretical under pinning. This was checked and compared using the signs of the parameters. The aprior of the study was presented below:

\subsubsection{Variables and Expectation Signs}

Table 1. Relationships between variables and expectation signs

\begin{tabular}{lc}
\hline Variable & Expected Sign \\
\hline Unemployment & Negative (-) \\
Poverty & Negative (-) \\
RGDP & Positive (+) \\
Loan & Positive (+) \\
\hline
\end{tabular}

The above table shows that according to theory, it is expected that unemployment, and poverty level, have a 
negative relationship with manufacturing sub-sector contribution to RGDP (RMSO), while RGDP and Loan have positive relationship with manufacturing sector contribution to RGDP (RMSO). This implies growth in the sector should lead to reduction in the unemployment rate as many of the unemployment populace would be employed, thereby alleviate their poverty level and contribute to the growth of Nigeria's GDP.

\section{Data Presentation and Analysis}

\subsection{Data Presentation}

Refer to Appendix 1.

4.2 Graphical Representation of Data

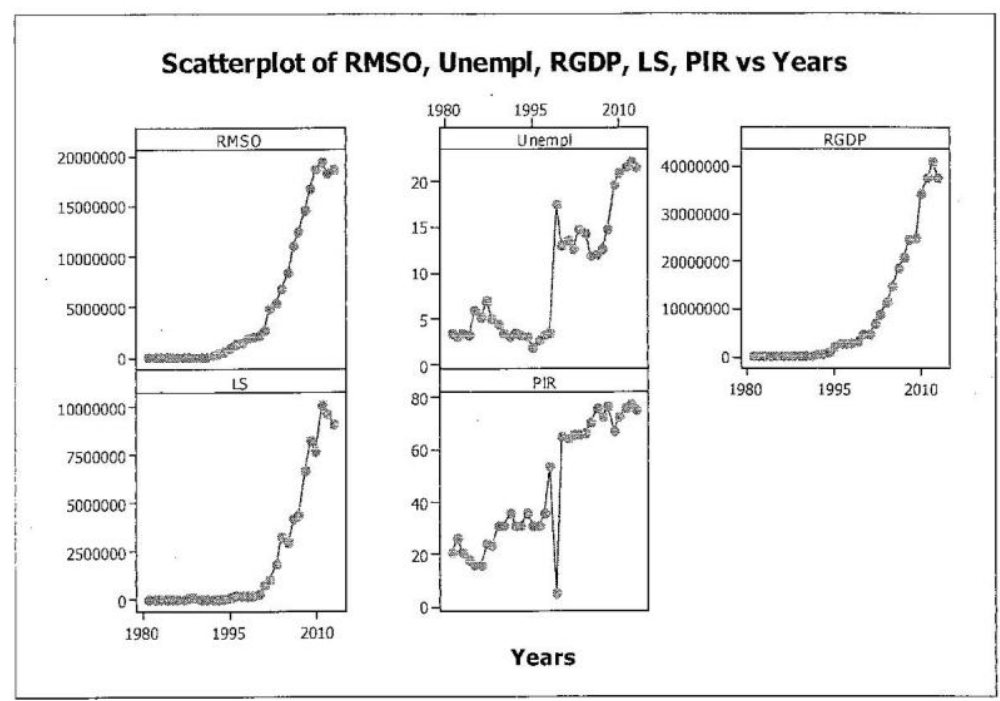

Figure 1. Scatter plot of variables from 1981 to 2012

Figure 1 shows trend of variable of interest from 1981 to 2012. From the figure, it can be deduced that RMSO increase significantly till 2009 but experience downward trend in the last, section of the years considered, as well as poverty level and Loan Assessment in the country. Both Poverty Level and Real GDP experience drastic fluctuation during the period.

\subsection{Correlation Analysis}

This is used for parsimony in regression analysis as it shows correlated independent variable among the independent variable in the model. As well known, multicollinearity is a problem in multiple regression which could affect the stability of regression model and often make the error term unpredictable over time. The analysis would shows independent variable to consider or remove in the model for better performance or better modeling. The result is as follows:

Table 2. Correlations: RMSO, Unempl, RGDP, LS, PIR

\begin{tabular}{lllll}
\hline Pearson Correlation (P-value) & RMSO & Unemp1 & RGDP & \\
\hline Unemp1 & 0.876 & & & \\
& 0.000 & & & \\
RGDP & 0.989 & 0.870 & & \\
& 0.000 & 0.000 & 0.987 & 0.000 \\
LS & 0.986 & 0.856 & 0.795 & 0.765 \\
PIR & 0.000 & 0.000 & 0.741 & 0.000 \\
\end{tabular}


Based on the correlation value of 0.876 for the relationship between unemployment and Real Manufacturing Sector, an increase in the activities of manufacturing sector in Nigeria did not lead to reduction in the number of unemployed populace probably due to advancement of technology that can be used for activities that suppose to be done by human being. This implies, the increase in unemployment in the country has insignificant effect on output of manufacturing sector as it was expected to have negative impact.

Moreover, Real GDP has positive effect on manufacturing sector and it is an indication of favourable coexistence of Nigeria RGDP and Real Manufacturing Sector Output. Among the independent variable, the correlation between Loan Assessment and RGDP is positively strong which is greater than 0.85. This implies one of the variables should be removed from the model to prevent multicollinearity. Removing Loan Assessment in the model, the independent variable becomes three in number.

\subsection{Regression Analysis}

From the first specified objective in section one, regression analysis was used to determine efficiency of NEEDS in Nigeria. This was done by dividing the data into two sections, namely; before the reform and during reform. Before reform include data from 1981 to 1998 while during was 1999 to 2012. The models were considered for proper comparison.

\subsubsection{Before Reform}

From equation 1, the model formulation is

$$
R M S O=B O+B 1 E M P+B 2 R G D P+B 3 L S+B 4 P L+e i
$$

But based on the model reduction, equation (1) becomes

$$
\mathrm{RMSO}=B O+B 1 E M P+B 2 R G D P+B 3 L S+e i
$$

In equation (1)**, Loan Assessment is removed from equation (1). Using E-views Software on data from 1981 to 1998, the result is as follows:

\begin{tabular}{|c|c|c|c|c|}
\hline \multicolumn{5}{|c|}{ Dependent Variable: Rmso } \\
\hline \multicolumn{5}{|l|}{ Method: Least Squares } \\
\hline \multicolumn{5}{|l|}{ Sample: 19811998} \\
\hline \multicolumn{5}{|l|}{ Included observations: 18} \\
\hline \multicolumn{5}{|c|}{$\mathrm{RMSO}=\mathrm{C}(1)+\mathrm{C}(2) * \mathrm{UNEMPL}+\mathrm{C}(3) * \mathrm{RGDP}+\mathrm{C}(4) * \mathrm{PIR}$} \\
\hline & Coefficient & Std.Error & $\mathrm{t}$-Statistic & Prob \\
\hline $\mathrm{C}(1)$ & -273984.2 & 94053.33 & -2.913072 & 0.0113 \\
\hline $\mathrm{C}(2)$ & 21203.40 & 1.491733 & 1.491733 & 0.1580 \\
\hline $\mathrm{C}(3)$ & 0.525429 & 0.021005 & 25.01413 & 0.0000 \\
\hline $\mathrm{C}(4)$ & 7711.300 & 2403.885 & 3.207849 & 0.0063 \\
\hline R-square & 0.990456 & \multicolumn{2}{|l|}{ Mean dependent var } & 446325.8 \\
\hline Adjusted R-squared & 0.988411 & \multicolumn{2}{|l|}{ S.D. dependent var } & 597924.6 \\
\hline S.C. of regression reside & 64366.86 & \multicolumn{2}{|l|}{ Akaike info criterion } & 25.17572 \\
\hline Long likelihood & $5.80 \mathrm{E}+10$ & \multicolumn{2}{|l|}{ Schwarz criterion } & 25.37358 \\
\hline F-statistic & -222.5814 & \multicolumn{2}{|l|}{ Hanna-Quinn criter. } & 25.20300 \\
\hline \multirow[t]{2}{*}{ Prob (F-statistic) } & 484.3187 & \multirow{2}{*}{\multicolumn{2}{|c|}{ Durbin-Watson stat }} & 1.155288 \\
\hline & 0.000000 & & & \\
\hline
\end{tabular}

Table 3. Results of E-views software for 1981-1998

Model formulated is:

$$
R M S O=273984.2+21203.4 U N E M P L+0.525 R G D P+7711.3 P I R
$$

The F-Ratio of the model is 484.32 which gives the p-value of the model to be less than 0.01 and it is an 
indication that the model is significant at $1 \% . \mathrm{R}^{2}$ of the model is $99 \%$ (Adj. $\mathrm{R}^{2}$ is $99 \%$ ) which implies the independent variable accounted for up to $99 \%$ of the fluctuation in the dependent variable. It can be noted that all the independent variable used have positive effect on the dependent variable.

\subsubsection{During Reform}

Data set from 1999 to 2012 was used and the result is as follows:

Table 4. Results of E-views software for 1999-2012

\begin{tabular}{|c|c|c|c|c|}
\hline \multicolumn{5}{|l|}{ Dependent Variable: Rmso } \\
\hline \multicolumn{5}{|l|}{ Method: Least Squares } \\
\hline \multicolumn{5}{|l|}{ Date: 10/16/13 Time: 04:45 } \\
\hline \multicolumn{5}{|l|}{ Sample: 19992012} \\
\hline \multicolumn{5}{|l|}{ Included observations: 15} \\
\hline \multicolumn{5}{|c|}{$\mathrm{RMSO}=\mathrm{C}(1)+\mathrm{C}(2) * \mathrm{UNEMPL}+\mathrm{C}(3) * \mathrm{RGDP}+\mathrm{C}(4) * \mathrm{PIR}$} \\
\hline & Coefficient & Std.Error & t-Statistic & Prob \\
\hline $\mathrm{C}(1)$ & 3432988 & 4501793 & 0.762582 & 0.4618 \\
\hline $\mathrm{C}(2)$ & -166526.6 & 234424.5 & -0.710363 & 0.4923 \\
\hline $\mathrm{C}(3)$ & 0.526006 & 0.082526 & 6.373843 & 0.0001 \\
\hline $\mathrm{C}(4)$ & -3736.019 & 38739.71 & -0.096439 & 0.9249 \\
\hline R-square & 0.958760 & Mean dependent var & & 10864789 \\
\hline Adjusted R-squared & 0.947512 & S.D. dependent var & & 6603504. \\
\hline S.C. of regression reside & 1512876. & Akaike info criterion & & 31.52010 \\
\hline Long likelihood & $2.52 \mathrm{E}+13$ & Schwarz criterion & & 31.70892 \\
\hline F-statistic & -232.4008 & Hanna-Quinn criter. & & 31.51809 \\
\hline \multirow[t]{2}{*}{ Prob (F-statistic) } & 85.24298 & Durbin-Watson stat & & 1.158128 \\
\hline & 0.000000 & & & \\
\hline
\end{tabular}

\section{$R M S O=3432988-166526.6 U N E M P L+0.526006 R G D P-3736.019 P I R$}

The F-Ratio of the model is 85.22 which gives the p-value of the model to be less than 0.01 and it is an indication that the model is significant at $1 \% \mathrm{R}^{2}$ of the model is $96 \%$ (Adj. $\mathrm{R}^{2}$ is $95 \%$ ) which implies the independent variable accounted for up to $95 \%$ of the fluctuation in the dependent variable. It can be noted that all the independent variable used have positive effect on the dependent variable.

\subsubsection{Model Comparison}

Comparing the models formulated, the model before the reform shows fluctuation in the manufacturing sector than during the reform period with significant parameter and positive effect. But considering the period of NEEDS in the country, poverty level has negative effect on manufacturing sector, as well as, unemployment rate. This shows that poverty level has inverse relationship with the output of manufacturing sector and the unemployment rate has inverse relationship with the output of manufacturing sector. Other factors have positive effect.

To determine the position to both poverty level and unemployment in the country, the data set was divided into two and compared for significant increase or decrease over time using Mann-Whitney test statistic at5\% level of significance. The result is as follows:
A. Mann-Whitney Test and CI: Unemployment before reform and Unemployment during reform.
N Median
U1 $18 \quad 4$
U2 $15 \quad 11075851$ 
Point estimate for ETA1-ETA2 is - 11075848

95.1 Percent CI for Eta1-ETA2 is (-16723164,-5449319)

$\mathrm{W}=171.0$

Test of ETA1 $=$ ETA2 vs ETA1 $\angle$ ETA2 is significant at 0.0000

The test is significant at 0.000 (adjusted for ties).

The p-value of 0.00 implies the null hypothesis should be rejected and alternative be accepted. This means unemployment rate before reform is significantly less than it was during the reform. That is, the reform in the sector did not lead to reduction in the rate of unemployment.

B. Mann-Whitney Test and CI: Poverty Level before reform and Poverty Level during reform.

N Median

P1 $18 \quad 31.30$

P2 $15 \quad 71.20$

Point estimate for ETA1-ETA2 is -41.90

95.1 Percent CI for Eta1-ETA2 is $(-46.80,-36.01)$

$\mathrm{W}=189.0$

Test of ETA1 $=$ ETA2 $v$ ETA $1<$ ETA2 is significant at 0.0000

The test is significant at 0.000 (adjusted for ties).

The p-value of 0.00 implies the null hypothesis should be rejected and the alternative be accepted. This means poverty rate before reform is significantly less than it was during the reform.

C. Mann-Whiteny Test and CI:RMSO before reform and RMSO during reform.

N Median

RMSO1 $18 \quad 139580$

RMSO2 $15 \quad 11075851$

Point estimate for ETA1-ETA2 is -10912116

95.1 Percent CI for Eta1-ETA2 is (-16571210,-5214920)

$\mathrm{W}=171.0$

Test of ETA1 $=$ ETA2 vs ETA $1<$ ETA2 is significant at 0.0000 .

The p-value of 0.00 implies the null hypothesis should be rejected and the alternative be accepted. This means RMSO before reform is significantly less than it was during the reform.

In conclusion, output of RMSO which increase after reform can be tagged as improvement in the sector as a result of NEEDS reform but the increase in both poverty level and unemployment rate implies the reform did not meet the target of mass reduction in poverty level of the populace, as well as, reduction in unemployment rate.

\section{Conclusion and Policy Recommendation}

The main objective of the research is to determine the impact if economic reform on manufacturing sector in Nigeria. Among the findings, during the reform, unemployment was on the increase as well as poverty level of the country. These are the problem NEEDS have to tackle as contained in the policy instrument.

Reform should be timely and effective in addressing the problem of the populace with proper follow-up by the policy makers, including the government.

NEEDS was formulated with correct and exact intention to address the lingering problem of the populace but could not capture those aims as set by the policy makers. The policy should include more emphasis on:

Rehabilitation and development of infrastructural facilities: Epileptic electricity and water supplies, as well poor telecommunication and transportation services which currently constrain industrial operations should be given priority attention by the government. There is urgent need to rehabilitate and expand them to aid industrial recovery and growth.

Job Creation: Government should pursue policy measures that will reinvigorate various sector of economy and enhance their employment generation potentials, including implementing a youth employment safety net 
programme that includes conditional cash transfer and vocational training, development of industrial cluster as well as reviewing of University curriculum.

Improvement in Standard of Living: The manufacturing sector should embark on high productivity as it has been acclaimed as a sure means of boosting economic growth and raising the standard of living of the people. Designing and implementing effective high productivity schemes have helped to pull many economies outs of recession and set them on the path of growth.

\section{References}

Adekoya, A. (1987). The role of government in promoting increase productivity on Nigeria firms. Proceeding of the National Conference on productivity, National productivity Centre, 1991, p. 56

Adenikinju, A., \& Chete, L. (n. d.). Productivity, market structure and trade liberalization in Nigeria economic development department. Nigeria institute of Social and economic research (AECR).

Adesanya, A. (2014). Nigeria records $7.7 \%$ growth in manufacturing sector- NBS/World Bank report. Retrieved January 23, $2004 \quad$ from http://www.worldstagegroup.com/worldstagenew/index.php?active=news\&newscid=13288\&catid=28

Akinlo, E. A. (1996). Improving the performance of the Nigeria manufacturing sub-sector after adjustment. The Nigeria Journal of Economics, and Social Studies, p. 9.

Alao, R. O. (2005). Improving the performance of the Nigeria: An error correction model (ECM). Paper presented in the department of Economics, University of Ilorin, Ilorin Nigeria, June 24.

Craig, C. E., \& Harris, R. C. (1973). Total productivity at the firm level. Sloan Manufacturing Review, Spring, $13-29$.

Federal Government of Nigeria. (2004). National Economic Empowerment and development Strategy (NEEDS). The NEED secretariat, National planning Commission, Federal Secretariat Abuja, March 2004.

MAN. (2010). Manufacturers association of Nigeria membership profit. Retrieved from http://www.manufacturersnigeria.org/membership.htm

Udo-Aka, U. (1983). Measuring productivity: Issues and problem in productivity in Nigeria. Proceedings of a National Conference, p. 75.

World Bank. (2010). GDP Ranking. Retrieved from http://data.worldbank.org/data-catalog/GDP-PPP

\section{Appendix 1. Variable of interest}

\begin{tabular}{lccccc}
\hline Year & RMSO & Unemp & RGDP & LS & PL \\
\hline 1981 & 31817.03 & 3.5 & 51731.79 & $35,642.4$ & 21.1 \\
1982 & 34644.58 & 3.1 & 53658.95 & $31,763.9$ & 26.4 \\
1983 & 39510.57 & 3.5 & 57963.31 & $36,307.5$ & 21.2 \\
1984 & 45151.77 & 3.4 & 64326.34 & $25,154.9$ & 18.3 \\
1985 & 49682.16 & 6.1 & 73542.02 & $44,242.1$ & 16.5 \\
1986 & 52754.12 & 5.3 & 74908.22 & $68,417.4$ & 16.4 \\
1987 & 70745.52 & 7 & 111912.93 & $102,152.7$ & 16.4 \\
1988 & 97884.99 & 5.1 & 147941.13 & $118,611.0$ & 24.6 \\
1989 & 127200.8 & 4.5 & 228451.46 & $129,300.3$ & 24 \\
1990 & 151958.6 & 3.5 & 281550.27 & $98,493.4$ & 31.3 \\
1991 & 175512 & 3.1 & 329070.75 & $82,107.4$ & 31.6 \\
1992 & 257858.5 & 3.5 & 555445.51 & $91,953.0$ & 36.4 \\
1993 & 401563.9 & 3.4 & 715241.87 & $80,845.9$ & 31.3 \\
1994 & 616300.1 & 3.2 & 945557.02 & $91,821.1$ & 31.6 \\
1995 & 1059327 & 1.9 & 2008564.01 & $163,938.6$ & 36.4 \\
\hline
\end{tabular}




\begin{tabular}{|c|c|c|c|c|c|}
\hline 1996 & 1409494 & 2.8 & 2799036.11 & $241,612.0$ & 31.6 \\
\hline 1997 & 1586060 & 3.4 & 2906624.88 & $242,028.2$ & 36.4 \\
\hline 1998 & 1826397 & 3.5 & 2816406.01 & $215,701.0$ & 54 \\
\hline 1999 & 2014464 & 17.5 & 3312240.87 & $244,994.5$ & 5.4 \\
\hline 2000 & 2222814 & 13.1 & 4717332.1 & $355,832.0$ & 65.4 \\
\hline 2001 & 2851003 & 13.6 & 4909526.48 & $808,820.1$ & 65.3 \\
\hline 2002 & 4869665 & 12.6 & 7128203.1 & $1,060,278.4$ & 66.3 \\
\hline 2003 & 5449325 & 14.8 & 8742646.65 & $1,892,278.4$ & 66.5 \\
\hline 2004 & 6800983 & 14.4 & 11673602.24 & $3,306,700.3$ & 67.3 \\
\hline 2005 & 8477348 & 11.9 & 14735323.98 & $3,064,718.5$ & 71.2 \\
\hline 2006 & 11075851 & 12.1 & 18709786.48 & $4,4263,060.3$ & 76.4 \\
\hline 2007 & 12571938 & 12.7 & 20940910.9 & $4,425,861.9$ & 73.2 \\
\hline 2008 & 14576815 & 14.9 & 24665244.17 & $6,721,074.6$ & 77.6 \\
\hline 2009 & 16723168 & 19.7 & 25236056.37 & $8,349,509.3$ & 67.6 \\
\hline 2010 & 18764948 & 21.1 & 34494582.71 & $7,740,507.6$ & 73.4 \\
\hline 2011 & 19432146 & 21.7 & 38016971.08 & $10,189,604.2$ & 76.5 \\
\hline 2012 & 18306754 & 22.3 & 41177818.59 & $9,706,761.2$ & 78.1 \\
\hline
\end{tabular}

Source: CBN Bulletin (2012), national Bureau of Statistics (2012).

\section{Copyrights}

Copyright for this article is retained by the author(s), with first publication rights granted to the journal.

This is an open-access article distributed under the terms and conditions of the Creative Commons Attribution license (http://creativecommons.org/licenses/by/3.0/). 